\title{
Dithiocarbamate Residues in Fruits and Leaves of Passion Fruit (Passiflora edulis) from Different Brazilian Regions
}

\author{
Joseane O. Mozzaquatro, ${ }^{a}$ Denise C. Mello, ${ }^{a}$ Reginaldo C. S. Oliveira, ${ }^{a}$ Raul C. C. Rosa ${ }^{b}$ \\ Ana M. Costa ${ }^{c}$ and Eloisa D. Caldas ${ }^{\circledR} * a$ \\ ${ }^{a}$ Laboratório de Toxicologia, Departamento de Farmácia, Universidade de Brasília, \\ 70910-900 Brasília-DF, Brazil \\ ${ }^{b}$ Embrapa Agrobiologia (CNPAB), Empresa Brasileira de Pesquisa Agropecuária (Embrapa), \\ 23891-000 Seropédica- RJ, Brazil \\ 'Embrapa Cerrados (CPAC), Empresa Brasileira de Pesquisa Agropecuária (Embrapa), \\ 73310-970 Planaltina- DF, Brazil
}

\begin{abstract}
Dithiocarbamates are widely used fungicides, including in passion fruit, whose fruits are mainly used for juice production, the leaves for the preparation of herbal tea and medicines. Also, the use of the peel in the food industry has been proposed. In this study, the spectrophotometric method for determination of dithiocarbamate residues, as $\mathrm{CS}_{2}$, in passion fruit (Passiflora edulis) was validated at a limit of quantification (LOQ) of $0.05 \mathrm{mg} \mathrm{kg}^{-1} \mathrm{CS}_{2}$, and 108 samples (55 fruits and 53 leaves) collected from Brazilian growers were analyzed. About $25 \%$ of the fruit peel samples were positive ( 0.06 to $\left.1.4 \mathrm{mg} \mathrm{kg}^{-1}\right)$ and only one sample had residues in the pulp $\left(0.09 \mathrm{mg} \mathrm{kg}^{-1}\right)$, $43.4 \%$ of leaf samples contained residues. Washing of fruit reduced the residues in the peel by up to $100 \%$, and drying the leaves increased residue levels by up to $60 \%$. This is the first study that reports dithiocarbamate residues in passion fruit in Brazil, and the results are important for government authorities when planning monitoring programs, and for food and herbal medicine industries.
\end{abstract}

Keywords: dithiocarbamates, $\mathrm{CS}_{2}$, passion fruit, Passiflora edulis, peel, leaf, Brazil

\section{Introduction}

Dithiocarbamates (DTCs) are non-systemic pesticides widely used to control fungal diseases in food / feed crops and ornamental plants. ${ }^{1}$ Some are small organic molecules, e.g., thiram, with a strong chelating ability towards inorganic species, and are formed by the reaction between carbon disulfide $\left(\mathrm{CS}_{2}\right)$ and either ammonium or a primary / secondary amine in the presence of sodium hydroxide or excess amine. ${ }^{2}$ The major concern regarding the health of the population consuming food sourced from dithiocarbamate-treated crops is in the degradation products of ethylene-bis-dithiocarbamates (EBDC, including mancozeb and metiram) and propineb (ethylene-thiourea and propylene-thiourea, respectively), which have been shown to cause thyroid cancer in rats. ${ }^{1-3}$

*e-mail: eloisa@unb.br
Five DTCs are registered in Brazil. ${ }^{4}$ Mancozeb, the most used DTC in the world, is the third pesticide most commercialized in Brazil, following the herbicides glyphosate and 2,4-dichlorophenoxyacetic acid (2,4-D), ${ }^{5}$ being registered for foliar or post-harvest treatment in 50 crops. Metiram is registered for use in 20 crops as foliar and / or soil treatment (only potato), propineb for foliar application in 9 crops, thiram for seed treatment in 12 crops and soil treatment in potato, and metam-sodium for soil treatment in 6 crops. Because of their non-systemic properties, residues of dithiocarbamates are not expected in mature crops after soil or seed treatment. Mancozeb and metiram are registered for foliar application to passion fruit. ${ }^{4}$

DTCs are the most commonly detected pesticides in residue monitoring programs in Brazil ${ }^{6,7}$ and elsewhere. ${ }^{8-10}$ They are not analyzed by multi-residue methods because of chemical characteristics very different from those of other pesticides, including their low solubility in 
most organic solvents and low stability. ${ }^{11}$ The classic method for the determination of dithiocarbamates quantifies the $\mathrm{CS}_{2}$ generated by the acid degradation of the compound present in the sample, which can be spectrophotometrically determined after complexation,, $712-14$ or by gas chromatography using different detectors. ${ }^{11,12-15}$ However, since all DTCs produce $\mathrm{CS}_{2}$, none of these methods allow the identification of the compound applied to the crop, and the results are expressed in $\mathrm{mg} \mathrm{kg}^{-1} \mathrm{CS}_{2}$. In Brazil, the maximum residue level (MRL) for DTCs in passion fruit (whole fruit) is $1 \mathrm{mg} \mathrm{kg}^{-1} \mathrm{CS}_{2}$.

Brazil is the world's largest producer of passion fruit (Passiflora sp.), with approximately 700,000 tons cultivated in an approximate area of 50,000 hectares. The Northeastern region, mainly the Bahia State, is responsible for about $70 \%$ of the national production, followed by the Southeast region $(14.5 \%){ }^{16}$ P. edulis Sims is the main commercial species, cultivated all year around in Bahia because of the warm temperature, and from September to May in the other Brazilian regions. The pulp is destined mainly for the production of concentrated juice, ${ }^{17}$ and the leaves used for the preparation of tea ${ }^{18}$ and as raw material in the herbal industry, being included in the Brazilian List of Medicinal Plants of Interest to the SUS (Relação Nacional de Plantas Medicinais de Interesse ao Sistema Único de Saúde (SUS)). ${ }^{19}$ There is also a growing interest to use passion fruit peel, which accounts for about 60 to $70 \%$ of the whole fruit weight, as an ingredient in the food industry due to its high soluble and insoluble fiber contents and other nutritional properties. ${ }^{20-23}$

DTC residue data on passion fruit are limited in the world and are nonexistent in Brazil. The objective of this study was to determine these fungicides in peel, pulp and leaf of passion fruit (P. edulis) samples collected directly from producers of different regions of the country using a validated spectrophotometric $\left(\mathrm{CS}_{2}\right)$ analytical method. Additionally, processing factors were estimated for peel from washed fruit compared with peel from unwashed fruit and for dry leaf produced from fresh leaf.

\section{Experimental}

\section{Samples}

A total of 108 passion fruit (55 fruits and 53 leaves) samples were collected directly from 51 Brazilian conventional growers from February 2016 to February 2018 in the Rio de Janeiro State (18 growers), Goiás State and the Federal District (16 growers) and Bahia State (17 growers) (Figure 1). In addition, samples of fruits and leaves from organic growers from Bahia State and the Federal District were collected for method validation. About $2 \mathrm{~kg}$ of passion fruit and $300 \mathrm{~g}$ of leaves were provided by each grower.

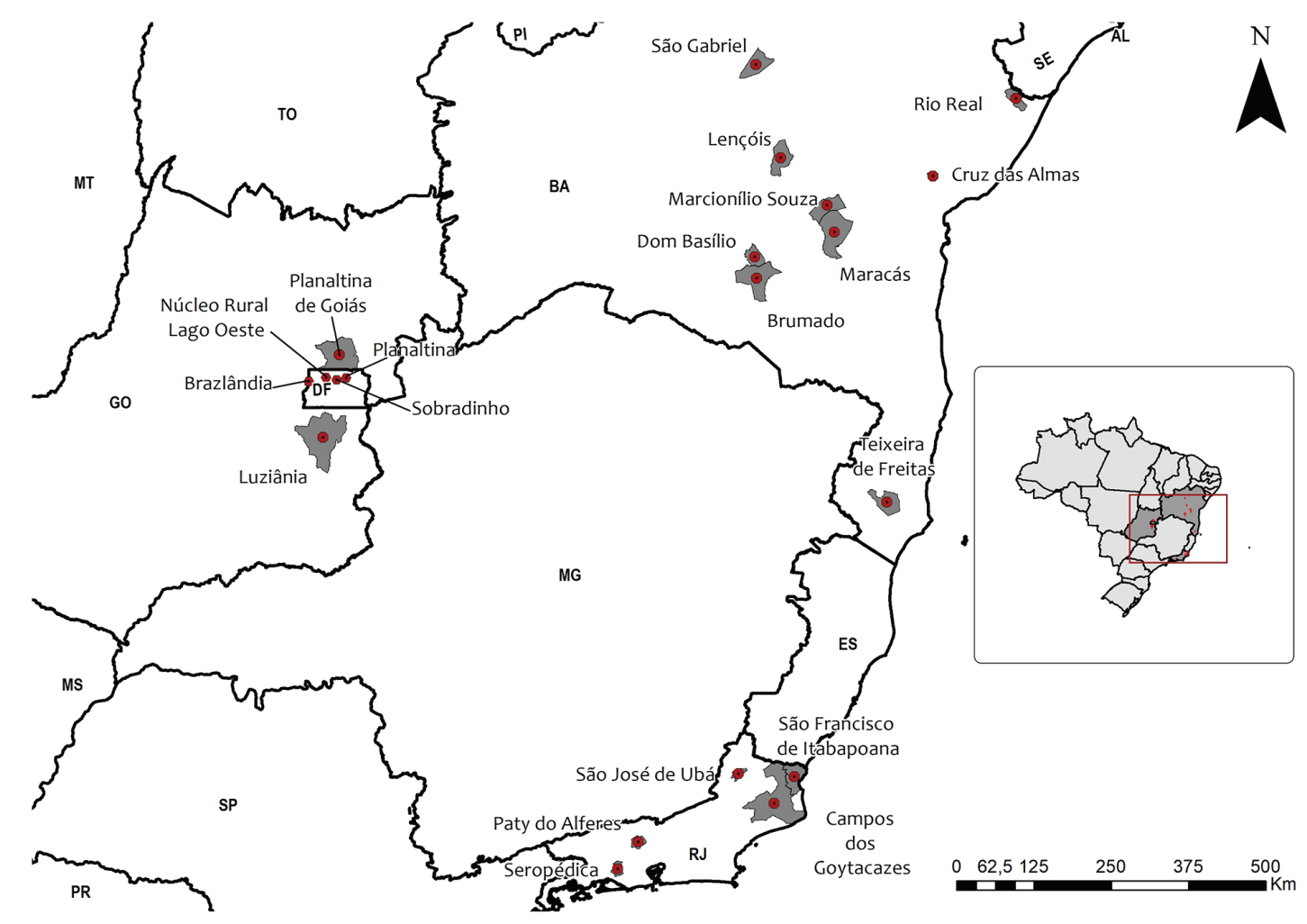

Figure 1. Collecting points of passion fruit (Passiflora edulis) samples from growers from Goiás, Bahia and Rio de Janeiro States and Federal District. 


\section{Sample processing}

Half of the passion fruit units in each sample provided was washed in running water for about $1 \mathrm{~min}$; washed and unwashed passion fruits were frozen, and then processed still frozen into peel, pulp and seed. The peel was cut into small pieces, homogenized and stored at $-15{ }^{\circ} \mathrm{C}$ until analyzis, as well as the seedless pulp. Portions of four passion fruit fresh leaf samples were submitted to the drying process using an industrial dryer with hot air circulation at an average temperature of $40{ }^{\circ} \mathrm{C}$ for about $20 \mathrm{~h}$, which mimics the process for dry leave production to be used as tea or herbal medicine. ${ }^{24}$ The other leaf samples were frozen, cut into smaller pieces and stored at $-15^{\circ} \mathrm{C}$ until analyzis. Processing the samples under frozen conditions is essential to prevent enzymatic degradation of dithiocarbamates. $^{12,13}$

\section{Reagents and instrumentation}

Carbon disulfide $\left(\mathrm{CS}_{2}\right.$, UV-HPLC grade), stannous chloride dehydrated $\left(\mathrm{SnCl}_{2} \cdot 2 \mathrm{H}_{2} \mathrm{O}\right)$ and copper(II) acetate $\left(\left(\mathrm{CH}_{3} \mathrm{COO}\right)_{2} \mathrm{Cu}\right)$ were obtained from Vetec (Duque de Caxias, RJ, Brazil). Diethanolamine and ethanol were obtained from Dinâmica (Indaiatuba, SP, Brazil), 35$38 \% \mathrm{HCl}$ from Anidrol (Diadema, SP, Brazil) and $\mathrm{NaOH}$ from Neon (Suzano, SP, Brazil). Thiram analytical standard (97.1\% purity) was obtained from AccuStandard (Connecticut, USA). UV-Spectrophotometer used (1650 PC) was from Shimadzu (Japan). The digestion and vertical system for dithiocarbamate analysis, as $\mathrm{CS}_{2}$, is shown in Figure 2.

Determination of dithiocarbamates, as $\mathrm{CS}_{2}$

The spectrophotometric determination of DTCs followed the method developed by Caldas et al. ${ }^{12}$ using the system shown in Figure 2a. In summary, $150 \mathrm{~g}$ of sample were transferred to a two-necked flask, the acid digestion solution $\left(20 \% \mathrm{HCl}\right.$ and $1.25 \% \mathrm{SnCl}_{2}$ ) was added and the flask placed in a heating system. One mouth of the flask was connected to $\mathrm{N}_{2}$ and another to the vertical system containing $10 \% \mathrm{NaOH}$ solution (trap 1) and the complexation ethanolic solution (trap 2; $0.48 \%$ copper acetate and $10 \%$ diethanolamine), which was stable for 3 months in the refrigerator. After 45 min of heating the flask, the complexation reaction product (trap 2; Figure 2b) was transferred to a calibrated $25 \mathrm{~mL}$ volumetric flask, the

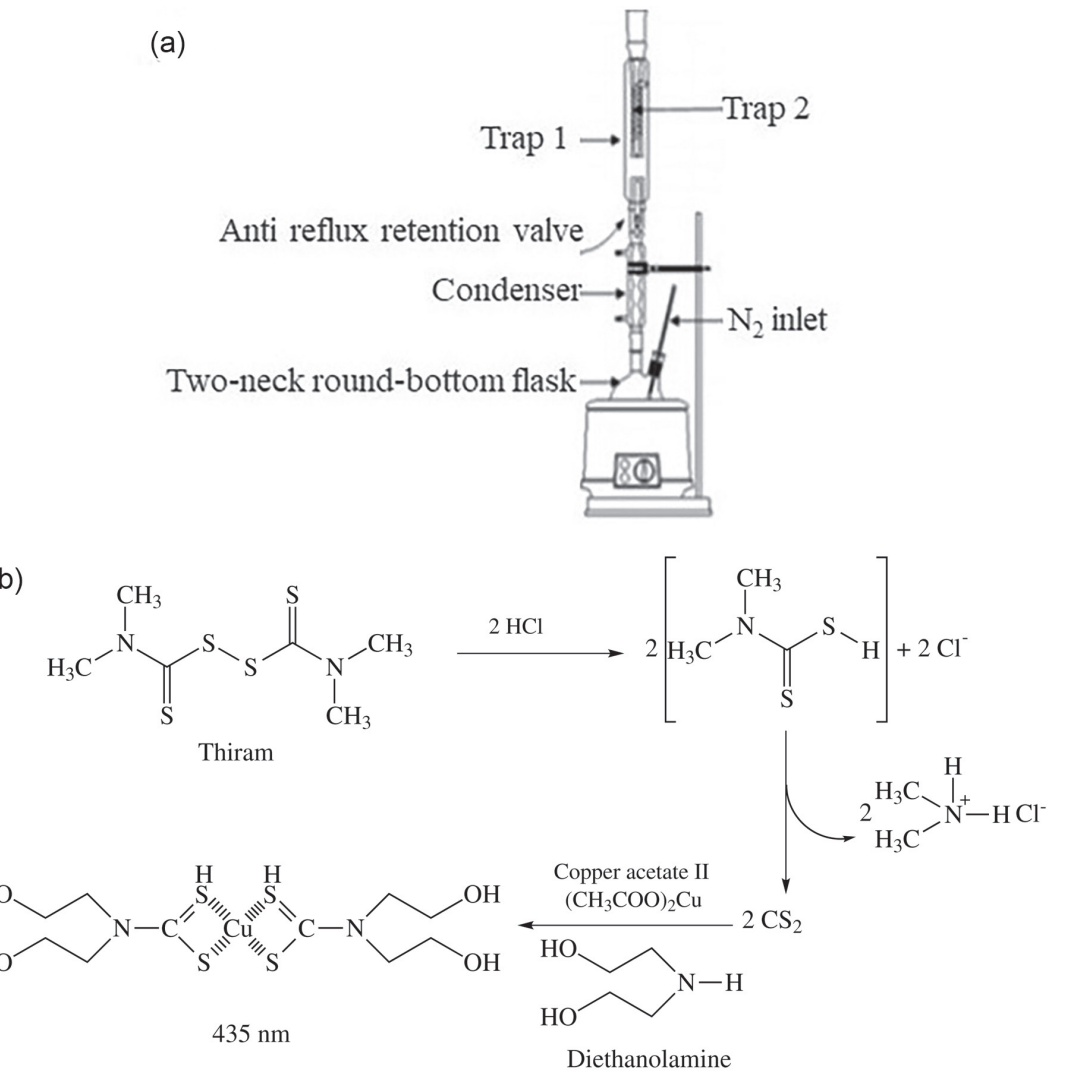

(b)

Figure 2. (a) Digestion and vertical systems for the analysis of dithiocarbamates in food samples. ${ }^{12}$ The $\mathrm{CS}_{2}$ generated by the acid hydrolysis in the flask is passed through a $\mathrm{NaOH}$ solution (trap 1) and is complexed with copper acetate/diethanolamine solution in trap 2. (b) Acid hydrolysis and complexation reactions for the dithiocarbamate thiram. 
volume filled with ethanol, and the yellow complex was measured in the spectrophotometer at $435 \mathrm{~nm}$ against an analytical curve of $\mathrm{CS}_{2}$, which was subjected to the same complexation reaction in $25 \mathrm{~mL}$ calibrated volumetric flasks. The hydrolysis and complexation reactions for thiram are shown in Figure $2 b$. The Laboratory of Toxicology is accredited by INMETRO (Brazilian Institute of Metrology, Quality and Technology) under ISO 17025 for this assay (CRL 0447).

\section{Method validation}

The validation parameters of the method were linearity of the analytical curve, limit of quantification (LOQ), accuracy (recovery in \%), repeatability and intermediate accuracy (expressed as \% of relative standard deviation, RSD), according to the European Commission criteria (SANTE/11813/2017). ${ }^{25}$ The linearity was evaluated by linear regression and correlation coefficient (r), by means of analytical curve with standard solution of $\mathrm{CS}_{2}$ at eight concentrations, from 0.21 to $8.4 \mu \mathrm{gLL}^{-1} \mathrm{CS}_{2}$, corresponding to 0.04 to $1.4 \mathrm{mg} \mathrm{kg}^{-1} \mathrm{CS}_{2}$. Thiram was the dithiocarbamate used during method validation, considering that $1 \mathrm{~mol}$ of thiram (240 g) yield 2 mols of $\mathrm{CS}_{2}(152 \mathrm{~g})$. A thiram (AccuStandard, USA) stock solution prepared in acetone and corresponding to $0.63 \mathrm{mg} \mathrm{mL}^{-1} \mathrm{CS}_{2}$ was used for the preparation of a working solution at $0.15 \mathrm{mg} \mathrm{mL}^{-1} \mathrm{CS}_{2}$ in ethanol, which was used to fortify passion fruit control matrices (peel, seedless pulp and leaf) at 0.05, 0.1, 0.2 and $1 \mathrm{mg} \mathrm{kg}^{-1} \mathrm{CS}_{2}$ levels, with five replicates for each level $(n=5)$. The repeatability was evaluated in the recovery trial (same day, same analyst), and expressed as RSD (\%). Additionally, fortified samples at 0.05 and $1.0 \mathrm{mg} \mathrm{kg}^{-1} \mathrm{CS}_{2}$ levels $(n=5)$ were analyzed by another analyst on another day to estimate the intermediate precision (total $n=10$ ). The limit of quantification (LOQ) of the method was defined as the lowest level of fortification that met the validation criteria (recovery between 70 and $120 \%$ and RSD lower than $20 \%){ }^{25}$ Samples whose concentration exceeded the upper limit of the standard curve were diluted to be estimated in the linear concentration range validated in the method. All control samples (from organic growers) showed negative results for dithiocarbamates, as $\mathrm{CS}_{2}$.

\section{Sample analysis and processing factor estimation}

First, peel samples of unwashed fruits were analyzed and those samples that presented concentration higher than the LOQ value had the peel samples from washed fruits and seedless pulp also analyzed. Pulps from fruit samples with negative results were not further analyzed. All leaf samples were analyzed. The processing factor $(\mathrm{PF})$, defined as the ratio of pesticide concentration in the sample after and the concentration before processing, ${ }^{26}$ was estimated for the peel, pulp and dry leaf, considering the processes of fruit washing, fruit fractionation and leaf drying. The $\mathrm{CS}_{2}$ concentration in the whole fruit was estimated for each sample from the concentrations of $\mathrm{CS}_{2}$ detected in the peel and in the pulp, and the weights of the peel and the whole fruit. When the concentration in the pulp was lower than LOQ, the level at the LOQ was used in the calculation. ${ }^{26}$

\section{Results and Discussion}

\section{Method validation}

The calibration curves of $\mathrm{CS}_{2}$ showed satisfactory results for linearity $(r>0.99)$ in the concentration range evaluated ( 0.21 to $8.4 \mu \mathrm{g} \mathrm{mL} \mathrm{CS}^{-1} \mathrm{CS}_{2}$, corresponding to 0.04 to $1.4 \mathrm{mg} \mathrm{kg}^{-1} \mathrm{CS}_{2}$ ). Table 1 shows the results of the method validation, with recoveries varying from 69.5 to $120 \%, 79.6$ to $112 \%$ and from 71 to $120 \%$ for peel, pulp (seedless) and leaf, respectively. The repeatability and intermediate precision were acceptable in all concentration ranges, with RSD lower than $12.6 \%$ in the three matrices. The LOQ value of the method was established at $0.05 \mathrm{mg} \mathrm{kg}^{-1} \mathrm{CS}_{2}$.

Table 2 shows the dithiocarbamate residues, in terms of $\mathrm{CS}_{2}$, of the passion fruit and leaf samples collected in the

Table 1. Recovery $(n=5)$, repeatability $\left(\operatorname{RSD}_{r}, n=5\right)$ and intermediate precision $\left(\operatorname{RSD}_{p}, n=10\right)$ of the spectrophotometric method for the analysis of dithiocarbamate (as $\mathrm{CS}_{2}$ ), in passion fruit matrices fortified at 3 or 4 concentration levels

\begin{tabular}{|c|c|c|c|c|c|c|c|c|c|c|c|}
\hline \multirow{2}{*}{$\frac{\text { Matrix }}{\text { Level / }\left(\mathrm{mg} \mathrm{kg}^{-1} \mathrm{CS}_{2}\right)}$} & \multicolumn{4}{|c|}{ Peel } & \multicolumn{3}{|c|}{ Pulp } & \multicolumn{4}{|c|}{ Leaf } \\
\hline & 0.05 & 0.10 & 0.20 & 1.0 & 0.05 & 0.10 & 0.20 & 0.05 & 0.1 & 0.2 & 1.0 \\
\hline Recovery / \% & 120 & 84.9 & 69.5 & 90.4 & 112 & 83.5 & 79.6 & 120 & 87 & 71 & 78 \\
\hline $\mathrm{RSD}_{\mathrm{r}} / \%$ & 0.7 & 2.1 & 12.2 & 6.0 & 4.8 & 1.9 & 2.2 & 10 & 8.7 & 12.6 & 3.1 \\
\hline $\operatorname{RSD}_{\mathrm{p}} / \%$ & 6.0 & - & - & 7.6 & 1.4 & - & 3.8 & 10.3 & - & - & 4.0 \\
\hline
\end{tabular}

RSD: relative standard deviation. 
three regions of the country (Figure 1). In total, 14 samples of passion fruit peel were positive for $\mathrm{CS}_{2}$ (25.4\% of the samples analyzed). Lower incidence of dithiocarbamate positive samples was found in Brazil for banana, cashew apple, grape, guava, mango, orange, pineapple and strawberry (1.8 to $16.3 \%)$, while apple, kaki, peach and papaya had higher incidence (32-59\%). ${ }^{7}$

Samples from the Middle West region (Goiás State and Federal District) were the most positive for dithiocarbamates (39.1\%). The levels in the whole fruit ranged from $<$ LOQ to $0.7 \mathrm{mg} \mathrm{kg}^{-1} \mathrm{CS}_{2}$, below the established MRL for dithiocarbamates in Brazil $\left(1 \mathrm{mg} \mathrm{kg}^{-1} \mathrm{CS}_{2}\right){ }^{4}$ No residues were found in passion fruit samples collected from the 17 producers of Bahia State, which are responsible for more than half of the country's passion fruit production, ${ }^{16}$ and only 2 of the 14 leaf samples were positive (Table 2), showing a limited use of dithiocarbamates by the passion fruit growers from this region.

The origin of $\mathrm{CS}_{2}$ determined in the sample could not be identified, which is a limitation of the indirect methods to quantify dithiocarbamates, regardless of the detection method used. ${ }^{11-15}$ Another limitation of the indirect methods is the possibility of false positive results in crops containing sulfur compounds, such as brassica (e.g., broccoli and cabbage), allium species (e.g., leek and onion) ${ }^{27}$ and papaya, ${ }^{13}$ a limitation that does not affect the analysis of passion fruit. Although there are specific methods for the determination of some dithiocarbamates in foods, mainly by high performance liquid cromatography (HPLC) using UV or mass spectrometric detectors, ${ }^{28-32}$ none can discriminate all the dithiocarbamate compounds, including mancozeb from metiram.

Due to the non-systemic characteristic of the dithiocarbamates, no residues are expected in fruit pulp. Indeed, only one sample (unwashed fruit) had $\mathrm{CS}_{2}$ in the pulp $\left(0.09 \mathrm{mg} \mathrm{kg}^{-1}\right)$, with an estimated processing factor (pulp / whole fruit) of 0.13 for this sample. In this study, care was taken not to mix the peel and the pulp during fruit fractionation, although cross contamination cannot be disregarded during industrial processing of passion fruit for juice production, considering that washing the fruit does not always remove all the residues (Table 2).

These are the first data of dithiocarbamate residues in Brazilian passion fruit, a crop that is not included in the Brazilian national monitoring programs for pesticide residues. ${ }^{33,34}$ Passion fruit is included in the European Food Safety pesticide monitoring program, being among the imported fruits with higher frequency of MRL exceedance..$^{8,35}$ In 2009, about $70 \%$ of the samples analyzed within the European program exceeded the MRL for dithiocarbamates $\left(0.05 \mathrm{mg} \mathrm{kg}^{-1} \mathrm{CS}_{2}\right)$, mostly samples from Kenya. ${ }^{35}$ Very limited data are available elsewhere. Hjorth et al. ${ }^{36}$ found 2 of the 18 passion fruit samples produced in Colombia containing residues of 0.34 and $1.9 \mathrm{mg} \mathrm{kg}^{-1} \mathrm{CS}_{2}$, above the European Union's MRL.

The use of passion fruit peel, rich in soluble fibers, as a food ingredient has been shown to have a positive effect in the glycemic and lipid levels of type 2 diabetes patients. ${ }^{37}$ In this study, a processing factor for passion fruit peel was estimated after the washing the fruit, a procedure performed in the juice industry. Of the $14 \mathrm{CS}_{2}$-positive peel samples from washed fruits, 4 had non-quantifiable residues (lower than LOQ), and the estimated median processing factor was 0.5 , representing $50 \%$ reduction of pesticides (Table 2). This estimate is close to that estimated by the German Federal Institute for Risk Assessment for dithiocarbamates in fruits and vegetables (0.11 to 0.62$).^{38}$ Reduction of dithiocarbamate residues after washing is expected since most residues of a non-systemic compound remain on the fruit surface.

Passion fruit leaves, including those of $P$. edulis, are used in the preparation of tea and as raw material in the herbal

Table 2. Dithiocarbamate residues $\left(\mathrm{CS}_{2}\right)$ in passion fruit samples and processing factors (PF) for washed peel and dried leaf

\begin{tabular}{|c|c|c|c|c|}
\hline & Rio de Janeiro State & $\begin{array}{c}\text { Goiás State and Federal } \\
\text { District }\end{array}$ & Bahia State & Total \\
\hline Peel, ${ }^{\mathrm{a}} \mathrm{p}(\mathrm{N})$ & $5(15)$ & $9(23)$ & $0(17)$ & $14(55)$ \\
\hline Level $^{\mathrm{b}} /\left(\mathrm{mg} \mathrm{kg}^{-1} \mathrm{CS}_{2}\right)$ & $0.06-0.3$ & $0.06-1.4$ & - & $0.06-1.4$ \\
\hline $\mathrm{PF}^{\mathrm{c}, \mathrm{d}}$ range (median), $\mathrm{N}=14$ & - & - & - & $0.1-1(0.5)$ \\
\hline Whole fruit, ${ }^{\mathrm{c}}$ level / $\left(\mathrm{mg} \mathrm{kg}^{-1} \mathrm{CS}_{2}\right)$ & $<$ LOQ-0.2 & $<$ LOQ-0.7 & - & $<$ LOQ-0.7 \\
\hline Fresh leaf, p (N) & $8(16)$ & $13(23)$ & $2(14)$ & $23(53)$ \\
\hline Level $^{\mathrm{b}} /\left(\mathrm{mg} \mathrm{kg}{ }^{-1} \mathrm{CS}_{2}\right)$ & $0.07-7.6$ & $0.1-8.5$ & $0.06-4.9$ & $0.06-8.5$ \\
\hline $\mathrm{PF}^{\mathrm{c}, \mathrm{e}}$ range (median), $\mathrm{N}=4$ & - & - & - & $1.1-1.6(1.3)$ \\
\hline
\end{tabular}

LOQ: limit of quantification; p: number of samples $\geq \mathrm{LOQ}$ of $0.05 \mathrm{mg} \mathrm{kg}^{-1} \mathrm{CS}_{2} ; \mathrm{N}$ : number of analyzed samples; afrom unwashed fruits; ${ }^{\text {range }}$ of positive samples; ' sample at $<\mathrm{LOQ}$ were considered at the LOQ in the calculation; ${ }^{\mathrm{P} F}$ for peel from washed fruit compared with peel from unwashed fruit; ${ }^{\mathrm{e}} \mathrm{PF}$ for dry leaf produced from fresh leaf. 
industry, being included in the Brazilian List of Medicinal Plants of Interest to the SUS. ${ }^{18}$ However, the Brazilian legislation proposed that medicinal plants be free from pesticide residues. ${ }^{39}$ The dried leaves of Passiflora sp. are included in the Brazilian Pharmacopeia ${ }^{40}$ and are used as a plant drug, mainly for its anxiolytic and sedative properties. ${ }^{41}$ More than $40 \%$ of passion fruit leaf samples analyzed in this study contained residues of dithiocarbamates, mainly samples from the Rio de Janeiro State (50\% of the samples), Goiás State and Federal District (56\%), indicating the frequent use of these fungicides by farmers in those regions. Although this use is allowed by the Brazilian legislation, in principle, products destined for the herbal medicine industry should not be treated with pesticides, even if the leaves are washed before drying. The level of $\mathrm{CS}_{2}$ present in the fresh leaves of $P$. edulis increased during the drying process, with a median processing factor of 1.3 (Table 2 ).

In addition to the dithiocarbamates, Brazilian growers have a limited number of pesticides registered in passion fruit, including kasugamycin, cartap and chlorfenapyr (MRL of $0.05 \mathrm{mg} \mathrm{kg}^{-1}$ ), difenoconazole and imidacloprid (MRL of $\left.0.2 \mathrm{mg} \mathrm{kg}^{-1}\right){ }^{4}$ The presence of these pesticides in passion fruit and the potential illegal use of other compounds should be further investigated.

\section{Conclusions}

The validation of the UV-Vis spectrophotometric method for the determination of dithiocarbamates in leaf, pulp and passion fruit peel matrices was satisfactory, with a LOQ of $0.05 \mathrm{mg} \mathrm{kg}^{-1} \mathrm{CS}_{2}$. About $25 \%$ of passion fruit samples and $43 \%$ of fresh leaf samples were positive, and no passion fruit samples contained residues above the Brazilian MRL (whole fruit). As expected for a nonsystemic compound, washing the fruit removed up to $100 \%$ of the surface residues; drying the fresh leaves increased the residue levels by up to $60 \%$.

This is the first study in the country that evaluated the levels of dithiocarbamates in passion fruit, and residue data from other pesticides in this crop are still lacking. The results of this work should be considered by the governmental authorities to include passion fruit in the pesticide monitoring programs, as well as to control the raw materials destined for the pharmaceutical industry (dry leaves) and food industry (peel as a by-product of juice production).

\section{Acknowledgments}

The authors would like to thank the passion fruit producers for providing the samples, and the Brazilian
National Council for Scientific and Technological Development $(\mathrm{CNPq})$ for the financial support.

\section{References}

1. Rubino, F. M.; Mrema, E. J.; Colosio, C.; Encycl. Food Saf. 2014, 3, 5 .

2. Kanchi, S.; Singh, P.; Bisetty, K.; Arabian J. Chem. 2013, 7, 11.

3. Belpoggi, F.; Soffritti, M.; Guarino, M.; Lambertini, L.; Cevolani, D.; Maltoni, C.; Ann. N. Y. Acad. Sci. 2002, 982, 123.

4. Agência Nacional de Vigilância Sanitária (ANVISA), http://portal.anvisa.gov.br/documents/111215/117782/ M02\%2B\%2BMancozebe.pdf/975fdd18-65fd-477c-ab85217bcb9a0110, accessed in April 2019.

5. Instituto Brasileiro de Meio Ambiente (IBAMA), www.ibama. gov.br/phocadownload/qualidadeambiental/relatorios/2017/01. Os_10_IAs_vendidos_2017.xlsx, accessed in April 2019.

6. Jardim, A. N. O.; Caldas, E. D.; Food Control 2012, 25, 607.

7. Jardim, A. N. O.; Brito, A. P.; van Donkersgoed, G.; Boon, P. E.; Caldas, E. D.; Food Chem. Toxicol. 2018, 112, 108.

8. European Food Safety Authority (EFSA), The 2016 European Union Report on Pesticide Residues in Food; EFSA J. 2018, 16, 5348 .

9. Ministério da Agricultura, Pecuária e Abastecimento (MAPA), http://www.agriculture.gov.au/ag-farm-food/food/ nrs/nrs-results-publications/plant-product-monitoring-201718\#horticulture-datasets, accessed in April 2019.

10. Valcke, M.; Bourgault, M. H.; Rochette, L.; Normandin, L.; Samuel, O.; Belleville, D.; Blanchet, C.; Phaneuf, D.; Environ. Int. 2017, 108, 63.

11. Crnogorac, G.; Schwack, W.; TrAC, Trends Anal. Chem. 2009, $28,40$.

12. Caldas, E. D.; Conceição, M. H.; Miranda, M. C.; Souza, L. C. K. R.; Lima, J. F.; J. Agric. Food Chem. 2001, 49, 4521.

13. Abakerli, R. B.; Sparrapan, R.; Sawaya, A. C. H. F.; Eberlin, M. N.; Jara, J. L. P.; Rodrigues, N. R.; Fay, E. F.; Luiz, A. J. B.; Galvão, T. D. L.; Martins, D. S.; Yamanishi, O. K.; Toledo, H. H. B.; Food Chem. 2015, 188, 71.

14. Pizzutti, I. R.; de Kok, A.; da Silva, R. C.; Rohers, G. N.; J. Braz. Chem. Soc. 2017, 28, 775.

15. Vareli, C. S.; Pizzutti, I. R.; Gebler, L.; Cardoso, C. D.; Gai, D. S. H.; Fontana, M. E. Z.; Talanta 2018, 184, 202.

16. Instituto Brasileiro de Geografia e Estatística (IBGE), https:// biblioteca.ibge.gov.br/visualizacao/periodicos/66/pam_2016_ v43_br.pdf, accessed in April 2019.

17. http://www.ceplac.gov.br/radar/maracuja.htm, accessed in April 2019.

18. Pineli, L. L.; Rodrigues, J. S.; Costa, A. M.; de Lima, H. C.; Chiarello, M. D.; Melo, L.; J. Sci. Food Agric. 2015, 95, 1500. 
19. http://portalarquivos2.saude.gov.br/images/pdf/2014/maio/07/ renisus.pdf, accessed in April 2019.

20. Oliveira, L. F.; Nascimento, M. R. F.; Borges, S. V.; Ribeiro, P. C. N.; Ruback, V. R.; Ciênc. Tecnol. Aliment. 2002, 22, 259.

21. Ishimoto, F. Y.; Harada, A. I.; Branco, I. G.; Conceição, W. A. S.; Coutinho, M. R.; RECEN 2007, 9, 280.

22. de Santana, F. C.; da Silva, J. V.; Santos, A. J. A. O.; Alves, A. R.; Wartha, E. R. S. A.; Marcellini, P. S.; da Silva, M. A. A. P.; Aliment. Nutr. 2011, 22, 391.

23. Miranda, A. A.; Caixeta, A. C. A.; Flávio, E. F.; Pinho, L.; Braz. J. Food Nutr. 2013, 24, 225.

24. Rocha, L.; Lucio, E. M. A.; França, H. S.; Sharapin, N.; Rev. Bras. Farmacogn. 2008, 18, 744.

25. European Commission Directorate General for Health and Food Safety; Guidance document on Analytical Quality Control and Method Validation Procedures for Pesticide Residues and Analysis in Food and Feed, SANTE/11813/2017, 21 and 22 November 2017 rev.0, https://ec.europa.eu/food/sites/food/files/ plant/docs/pesticides_mrl_guidelines_wrkdoc_2017-11813. pdf, accessed in April 2019.

26. Hamilton, D.; Yoshida, M.; Wolterink, G.; Solecki, R.; Food Safety Assessment of Pesticide Residues; World Scientific: New Jersey, USA, 2017, ch. 4.

27. Perz, R.C.; van Lishaut, H.; Schwack, W.; J. Agric. Food Chem. 2000, 48, 792.

28. Crnogorac, G.; Schmauder, S.; Schwack, W.; Mass Spectrom. 2008, 22, 2539.

29. Hayama, T.; Takada, M.; Anal. Bioanal. Chem. 2008, 392, 969.

30. López-Fernández, O.; Rial-Otero, R.; González-Barreiro C.; Simal-Gándara, J.; Food Chem. 2012, 134, 366.

31. Schmidt, B.; Christensen, H. B.; Peterse, A.; Sloth, J. J.; Poulsen, M. E.; Food Addit. Contam., Part A 2013, 30, 1287.

32. Pheta, N. H.; Lokhande, R. S.; Seshadri, D. T.; Patil, R. M.; Bhagat, T. S.; Patil, J. G.; Anal. Methods. 2017, 9, 4702.

33. Ministério da Agricultura, Pecuária e Abastecimento (MAPA); Plano Nacional de Controle de Resíduos e Contaminantes em Produtos de Origem Vegetal, PNCRC/VEGETAL, http:// www.agricultura.gov.br/assuntos/inspecao/produtos-vegetal/ copy_of_pncrc-vegetal, accessed in April 2019.

34. Agência Nacional de Vigilância Sanitária (ANVISA); Programa de Análise de Resíduos de Agrotóxicos em Alimentos (PARA), http://portal.anvisa.gov.br/programa-de-analise-de-registro-deagrotoxicos-para, accessed in April 2019.

35. European Food Safety Authority (EFSA), The 2009 European Union Report on Pesticide Residues in Food; EFSA J. 2011, 9, 2430.

36. Hjorth, K.; Johansen, K.; Holen, B.; Andersson, A.; Christensen, H. B.; Siivinen, K.; Toome, M.; Food Control 2011, 22, 1701.

37. Janebro, D. I.; de Queiroz, M. S. R.; Ramos, A. T.; Sabaá-Srur, A. U. O.; da Cunha, M. A. L.; Diniz, M. F. F. M.; Rev. Bras. Farmacogn. 2008, 18, 724.

38. The German Federal Institute for Risk Assessment; Pesticide Processing Factors, http://www.bfr.bund.de/en/search. html? search $\% 5$ Bquery $\% 5 \mathrm{D}=$ processing+factor, accessed in April 2019.

39. Agência Nacional de Vigilância Sanitária (ANVISA), Resolução da Diretoria Colegiada - RDC No. 26, de 13 de maio de 2014; Dispõe sobre o Registro de Medicamentos Fitoterápicos e o Registro e a Notificação de Produtos Tradicionais, Fitoterápicos, http://bvsms.saude.gov.br/bvs/saudelegis/ anvisa/2014/rdc0026_13_05_2014.pdf, accessed in April 2019.

40. Agência Nacional de Vigilância Sanitária(ANVISA); Formulário de Fitoterápicos da Farmacopéia Brasileira, http://portal. anvisa.gov.br/documents/33832/259456/Suplemento+FFFB. pdf/478d1f83-7a0d-48aa-9815-37dbc6b29f9a, accessed in April 2019.

41. Deng, J.; Zhou, Y.; Bai, M.; Li, H.; Li, L.; J. Ethnopharmacol. 2010, 128, 148.
Submitted: January 11, 2019

Published online: May 14, 2019 